\title{
The Application of Multimedia Technology in English Situational Teaching
}

\author{
Wen Li \\ Jiangxi Technical College of Manufacturing, Nanchang,330095
}

Keywords: Multimedia; Situational teaching; English teaching

\begin{abstract}
The combination of multimedia and foreign language teaching can make the functions of text, sound, image and animation of the teaching activities together, and can mobilize and stimulate students' enthusiasm and initiative to improve teaching efficiency. The application of multimedia-assisted teaching methods in the field of education and teaching will lead to profound changes in teaching content and teaching mode, and eventually lead to the fundamental changes of educational ideas and teaching methods. Exploration on how to use multimedia to support teaching methods in high school English scene teaching ability, especially the multimedia environment teaching effect, and what advantages and disadvantages of it whencompared with traditional classroom and other problems in recent years isthe hot spot. This article emphasizedthat we need to treat the students as the subject of cognition, the active constructor of English knowledge, and discussed how to use the multimedia assistant teaching method to carry on the English scene teaching in theory and practice.
\end{abstract}

\section{Introduction}

With the development of society, the development of science and technology, multimedia-assisted teaching has gradually become a new and modern teaching method, with its scientific nature, advanced nature, vividness and intuition, it has become the best choice for classroom teaching. Therefore, it is imperative to fully understand the advantages of multimedia-assisted teaching and to apply multimedia and other teaching media to English classroom teaching. Besides, the biggest beneficiariesof multimedia-assisted teaching methods applied to high school English situational teaching are students. Their curiosity is very strong, but affected by the traditional concept, teaching mode, teaching methods and meansof education, the English classroom is difficult to form a positive interaction, over time, the classroom becomes monotonous boring, so students will inevitably feel tired of learning English, which is always a big problemto plague a foreign language teaching. This article studied the application of multimedia technology teaching methods to English language teaching will give full play to the teacher's leading role and the student's main role, furtherimprove students' learning efficiency and academic performance.

\section{The Congenital Advantage of Multimedia English Teaching}

Attract Students' Attentionand Stimulate Interest in Learning ENGLISH. Multimedia English teaching are visual, intuitive and effective. The animation effect of other teaching methods can not be replaced. It can most effectively change the abstract knowledge to visual and concrete, easy to be mastered by the students. The interaction of teaching content and students are more organically combined to fully mobilize the enthusiasm of students. The characteristics of the combination of static and dynamiccan fully reproduce the language scene, and the knowledge resort can be showed by the mixture of screen, sound and painting. Teaching content are more specific, more vivid, people such as immersive, easy to learn happy, have fun, thus deepen understanding. Thus, the students become "learning" as "enjoying". Not only attract students' attention, but also stimulate students' interest to learn English.

Use Multimedia-Assisted Teaching to Increase the Classroom Teaching Capacity, Improve Teaching Efficiency. Multimedia make full use of modern science and technology, with a large teaching advantages, such as breaking the educational information dissemination of the "time", 
"empty" boundaries, so that a wider, faster, more distant range of information can be transmitted, kind of feeling can be extended, teaching vision is expanded, teaching time is relatively shortened. Multimedia-assisted teaching can fully mobilize students' initiative and enthusiasm, speed up classroom rhythm, increase classroom information capacity, increase the amount of language input, as far as possible provide more opportunitiesfor each student to attend in language practice.

Use Special Features of Multimedia to Highlight the Teaching Focus, Break through the Difficulties. Multimedia breaks throughthe boundariesof the oral and text the traditional teaching, making the oral, text, audio and video vividly show the object of understanding. Some special features such as: flashing, discoloration of a word, letters, sound and light synchronization of the animation screen, expand or shrink a certain point, elongated or abbreviated a sentence, can mobilize the students' ability to observe and memorize.

\section{The Application Principle of Multimedia in English Situational Teaching}

The Principle of Adaptability of Background Knowledge. Some of the English textbooks are widely available, covering a wide range of British and American culture, history, customs, places of interest and other background knowledge, as well as some professional knowledge and popular science knowledge. If students do not have this knowledge, it will be more difficult to understand in learning. Many students lack of large knowledge horizon, in order to prompt students to studybetter,which requires the courseware design presented the students a certain background knowledge, so that studentsknowthe backgroundbeforethe lesson, to facilitate they have a comprehensive and in-depth understandingin their teaching materials.

The Principle of Subjectivity Education. In the teaching process, we should pay attention to graspthe main and object positionof the students and teachers. Teachers can not regard students as the object and object of education, one side emphasizes the active side of students, obliterate the active side, suppress students' initiative, enthusiasm and creativity in the teaching process, but should treat students as the main body, fully develop its main body position. On the one hand, from the student's point of view, to perceive teaching materials, master the word, understand the discourse and training language communication skills, in order to determine the difficultiesto breakthrough teaching, strengthen the teaching focus and objectives, and in the media design it can be achieved. On the other hand, through the students placed in the teacher's position to design courseware. To provide students with content-rich, moderate degree of emotional materials, so that students through continuous training to understand teaching materials, and then use them.

The Principleof Intuitive Teaching Content. Courseware should be designed so that students exposed to three-dimensional composing ofspaceaudio and video, voice, text, from the vocabulary, sentences, discourse intuitive teaching. So that the body of a variety of organs can perceive information, to achieve three-dimensional teaching process, and greatly attracted the attention of students. The computer takes three-dimensional way to input the contents of the central processing unit and output, also in three-dimensional to display, thengive the brain the three-dimensional language learning, provide advanced teaching methodsfor teaching of ability. A large number of intuitive and dynamic English courseware will be directly inputthe language symbol and the scene consistent with the information to the students, change the abstract as specific, break through the difficulties; deepen understanding, it will be better than students listen to language symbols and then imagine the scene.

\section{The Application of Multimedia Creation in Teaching}

Use Multimedia to Create the Introduction Scene. The introduction of the text is mainly through the creation of a variety of situations, to provide students with English practiceas much as possible, from the most physical, action, exquisite color pictures, slides, recordings, videos, performances and songs, games and other means to use computer software for situational teaching. For example: in the introduction of Christmas customs, first broadcast a Christmas atmosphere rich "We Wish You a Merry Christmas", so that students enjoy music while thinking and Christmas-related scenes, 
which can mobilize students' excitement and interest in learning, as they can be in a relaxed, pleasant atmosphere, it will lay the foundation for learning.

Use Multimedia to Create Text Content Problem Scene. The use of multimedia resources to create text content situationcan lead students' desire to explore, to cultivate students' ability to observe and think. For example, when it comes to the date of Christmas, we can use the multimedia combination of audio-visual teachings to present the story of the Bible in the presentation of a picture of the Virgin Mary and Jesus, accompanied by the song "The Song of Our Lady". And then ask "Who knows something about the music? Do you know something about Jesus Christ? Do you know the meaning of Christ? Students know what kind of man he is. Help students understand their performance. In the teaching, to make full use of multimedia resources to create problem situations, so that students through the perception to stimulate interest and explore the theme, so as to cultivate the students' ability to observe and think.

Use Multimedia to Create the Scene to Consolidate the Classroom Contents. In English teaching, in order to grasp the basic knowledge of language and language skills, we always want to add some relevant knowledge and homework, to consolidate the content of classroom teaching. In the handling of the exercises, multimedia provides us with the conditions. From the type of design patterns, the purposebeing achieved, you can use a different effect shows that this creative, this large-density, fast-paced classroom structure greatly attracted the attention of students. So that the teaching is lively and interesting, focused, artistic, information, and the pace of the classroom speed up, students can get more sensory learning, good memory, learning effect will be better, so that students can unconsciously convert the knowledge into ability.

\section{Summary}

English learning requires a good environmentto learn and use thelanguage. Multimedia technology teaching has the visual, vivid characteristics, using multimedia technology teaching to provide the scene with abundant emotion, to stimulate students' interest in learning, enrich the students learning materials, in order to stimulate students'enthusiasm to learn and useEnglish. Multimedia combination teaching can provide students with a large number of practical and intuitive material, through the visual, hearing and other senses, to promote students from the vivid and intuitive to start the process to understand themselves. The application of multimedia combination teaching, the cultural background andlanguage scene of foreign language, through video, projection, computer and others become a concrete image, students in a harmonious, natural, relaxed environment to fully perceive teaching materials. In the English classroom teaching, teachers should do everything possible to use the real objective environment and multimedia creation scenes for English teaching, to optimize the classroom teaching process, further improve teaching efficiency.

\section{References}

[1] Abbott G. Development, education, and English language teaching[J]. Elt Journal, 1992, 46(2).

[2] Cheng A, Wang Q. English Language Teaching in Higher Education in China: A Historical and Social Overview[J]. 2012.

[3] Cheng A, Wang Q. English Language Teaching in Higher Education in China: A Historical and Social Overview[J]. 2012.

[4] England H E F C F. The sustainability of learning and teaching in English higher education[J]. Hefce, 2008.

[5] Alrashidi, Oqab|Phan, Huy. Education Context and English Teaching and Learning in the Kingdom of Saudi Arabia: An Overview[J]. English Language Teaching, 2015, 8(5).

[6] Yamada M. The Role of English Teaching in Modern Japan: Diversity and multiculturalism through English language education in a globalized era[J]. 2015.

[7] Buchanan J M. English Education and the Teaching of Literature.[C]// CEA Forum. College English Association. Web site: http://www.cea-web.org, 2016.

[8] Dirgayasa I W. Survey of English Teaching and Learning Process in Maritme Education and 
Training in Indonesia: A Case Study in Private MET in Indonesia[J]. English Language Teaching, 2014, 7(7).

[9] Xiao M. On the Roles and Ways of Humanistic Education in English Teaching of Vocational colleges[J]. Journal of Shanxi Institute of Economic Management, 2015, 13(1):135-7.

[10] Delarriva O, Alejandro E. Reading Logs and Literature Teaching Models in English Language Teacher Education[J]. HOW, 2016, 22: 37-53.

[11] Morrell E, Scherff E A. New Directions in Teaching English: Reimagining Teaching, Teacher Education, and Research[J]. 2015.

[12]López A, Sheila. Giftedness and English Teaching in Primary Education: Intervention Proposal[J]. Semiotica, 2015, 21(1-2):75-110. 